\title{
Lacustrine chalky carbonates: origin, physical properties and diagenesis (Palaeogene of the Madrid Basin, Spain)
}

\author{
M.E. Arribas ${ }^{\mathrm{a}, *}$, A. Bustillo ${ }^{\mathrm{b}}$, M. Tsige ${ }^{\mathrm{c}}$ \\ ${ }^{a}$ Dpto. de Petrología y Geoquímica, Facultad de Ciencias Geológicas, Universidad Complutense, Madrid 28040, Spain \\ ${ }^{\mathrm{b}}$ Dpto. de Geología, Museo Nacional de Ciencias Naturales CSIC, José Gutiérrez Abascal 2, Madrid 28006, Spain \\ ${ }^{\mathrm{c}}$ Dpto. de Geodinámica. Facultad de Ciencias Geológicas, Universidad Complutense, Madrid 28040, Spain
}

\begin{abstract}
The Palaeogene lacustrine chalky carbonates of the Madrid Basin are a peculiar type of very soft and friable carbonate facies with high porosity despite being covered by more than $800 \mathrm{~m}$ of sediment. Similar physical properties to those described in marine chalk reservoirs emphasize the interest in analysing and characterizing these carbonate facies within a lacustrine depositional system. Lithologically, they are calcitic and/or dolomitic poorly cemented carbonate muds with no significant amounts of skeletal debris. Clay minerals such as illite, smectite and palygorskite are present between the carbonate crystals. Palygorskite is the most common, covering the carbonate crystals and forming sheets between them. These lacustrine chalky carbonates were formed in the basinal areas of the lake as the result of inorganic carbonate precipitation and/or detrital sedimentation related to episodic reactivation of the adjacent fan systems. Their petrological, geochemical and physical properties indicate that few textural and compositional modifications occurred during diagenesis. Their main physical properties are a very low dry bulk and grain density $\left(1.6-2.2\right.$ and $2.62 \mathrm{~g} / \mathrm{cm}^{3}$, respectively) and medium to high porosity $(10-$ $40 \%)$ due to micropores $(<2 \mu \mathrm{m}, 70 \%)$ and macropores $(>2 \mu \mathrm{m}, 30 \%)$. The convergence of lacustrine sedimentation dynamics (rapid sedimentation), the original mineralogy of these calcareous lacustrine muds (relatively stable low-magnesian calcite and dolomite), the early formation of the palygorskite cement of these muds, and the retention of Mg-enriched fluids in the pore system, were decisive in the partial inhibition of calcite cementation, compaction and recrystallization. The chalky carbonates are also intercalated between impermeable littoral carbonate facies that impeded fluid flow through their pore systems.
\end{abstract}

Keywords: Chalky carbonates; Lacustrine deposits; Physical properties; Overpressure; Palygorskite; Palaeogene

* Corresponding author. Tel.: +34-91-394-4907; fax: +34-91544-2535.

E-mail addresses: earribas@geo.ucm.es (M.E. Arribas), abustillo@mcnc.csic.es (A. Bustillo), meaza@geo.ucm.es (M. Tsige).

\section{Introduction}

Traditionally, chalk is defined as a light-coloured, fine-grained, porous, friable carbonate rock of marine origin (Ziljstra, 1995). Chalks are pelagic carbonate muds composed mainly of calcareous tests of the floating microorganisms and of remains of calcareous algae (Schlanger and Douglas, 1974; Ziljstra, 1995). 
Due to the preservation of interparticle primary p rosity that chalks $\bullet$ ften present these deposits may constitute important carbonate reservoirs. Før this reasø, the petrøløical and physical characterizations - f marine chalks have been of special interest in the research int carbønate reservoirs (Schö1le, 1974; Schölle, 1977; Feazel and Schatzinger, 1985; Maliva and Dicksøn, 1992; H॰lail and L•hmann, 1994). More ver, limestone petrøleum reservirs shøwing a high porøsity, commøn in Mesøzic and Tertiary carbønate platform depøsits (Møshier, 1989), had been characterize as chalky texture carbøates, due to their similarity to chalks.

Analøgøus facies in continental envirønments were described by Kelts and Hsü (1978). These authors use the term chalk to describe lacustrine sediments typically fine grained and porous, either rhythmically laminate or massive, white to dull-yellowish grey. In this case, the bulk carbonate content boundary is around $60 \%$ and the dominant mineral is calcite. Lacustrine chalks have been described only rarely in the geløgical record (Kelts and Hsü, 1978; Gierløwski-Kordesch and Kelts, 1994; Krenmayr, 1997; Manikowska, 1997), some of them •ccurring in glacial lakes. Kelts and Hsü (1978) p•inted out that, in contrast to the oceans, the main source of these lacustrine carbonates is inorganic precipitation.

Fine-grained, light-coløure carbønate depøsits with high porsity $(10-40 \%)$ and friability $\bullet c c u r$ in the Palaegene lacustrine depesits of the Madrid basin (Arribas and Bustill॰, 1985; Bustill॰ et al., 1998; Bustill et al., 2002). There is a similarity in physical properties with chalks described in the literature (both marine and lacustrine in origin), but the carbonate particles are crystals and non-skeletal debris. As a result we propose using the term chalky carbonates for these facies, because they are not true chalks in the sense that Zijlstra (1995) considered.

Bustill• et al. $(1998,2002)$ described these carb॰nates and linked their origin to the early formation of an inorganic carbonate sediment. However, they still pose several interesting and unanswered questions, which are examine in this study: Why do these facies, interlaid with limestones and dolostones, preserve high poresity? Why are they the purest carbnates of the Palaegene lacustrine sequences? What is the sedimentological significance of these facies? Why is there a drastic change in the mineralogical compesition (calcitic and dolømitic) between the different beds? The petrølogy of chalky carbønates with the characterization of their physical properties will help to understand the origin of these facies, retention of poresity and diagenetic evelution.

\section{Geological setting}

Palae@gene deposits are scattered along the northeast border of the Madrid Basin and are synchronøus with the Alpine $\bullet$ reneny. The Palae gene $\bullet$ utcrøps are nearest the area of convergence between the Iberian Range and the Central System (Fig. 1A). The greater part of the Palaeøgene depesits in this area are carbønate and detrital rocks ordered in a succession formed by tw lithølegical units: the Carbønate and Detrital Units (Arribas, 1986a, b, 1994). These units are apparently conformable over an evaporitic unit that is possibly Palaegene. Neogene sediments are more than $\mathbf{2 0 0 0} \mathrm{m}$ thick, and unconformably overlie Palae gene and/or Cretaceous formations in the marginal parts of the basin (Vicente et al., 1996).

The Palaeøgene deposits reflect a change from a lacustrine environment (Carbonate Unit) to prograding alluvial fans (Detrital Unit) originating in the Central System and Iberian Range (Arribas and Arribas, 1991). This Palae gene carbønate-detrital succession shows changes in its lateral facies between the stratigraphic sections, although development over time was similar in each. These changes in the facies allowe three sectors to be identified by Arribas (1986b): Beleña de Sorbe, Huérmeces del Cerrø and Torremocha de Jadraque sectors (Fig. 1B and C). The detailed petrographic analysis of the nature of rock fragments in the Palaenene sandstones permits two source areas to be characterized (Arribas and Arribas, 1991): (i) Mesøzic sedimentary rocks (essentially limestones and dolostones) of the Iberian Range, in the east (Torremocha de Jadraque and Huermeces sectørs) and (ii) Palae zøic metamørphic basement (schists and slates) and Cretaceous cover of the Central System (limestones and dolostones) in the west (Beleña de Sorbe sector).

The Carbonate Unit reaches a maximum thickness of $500 \mathrm{~m}$ in the Torremocha de Jadraque sector, and a minimum of $200 \mathrm{~m}$ in the Huérmeces del Cerro sector. In the Beleña de Sorbe sector, the Carbonate Unit 
A

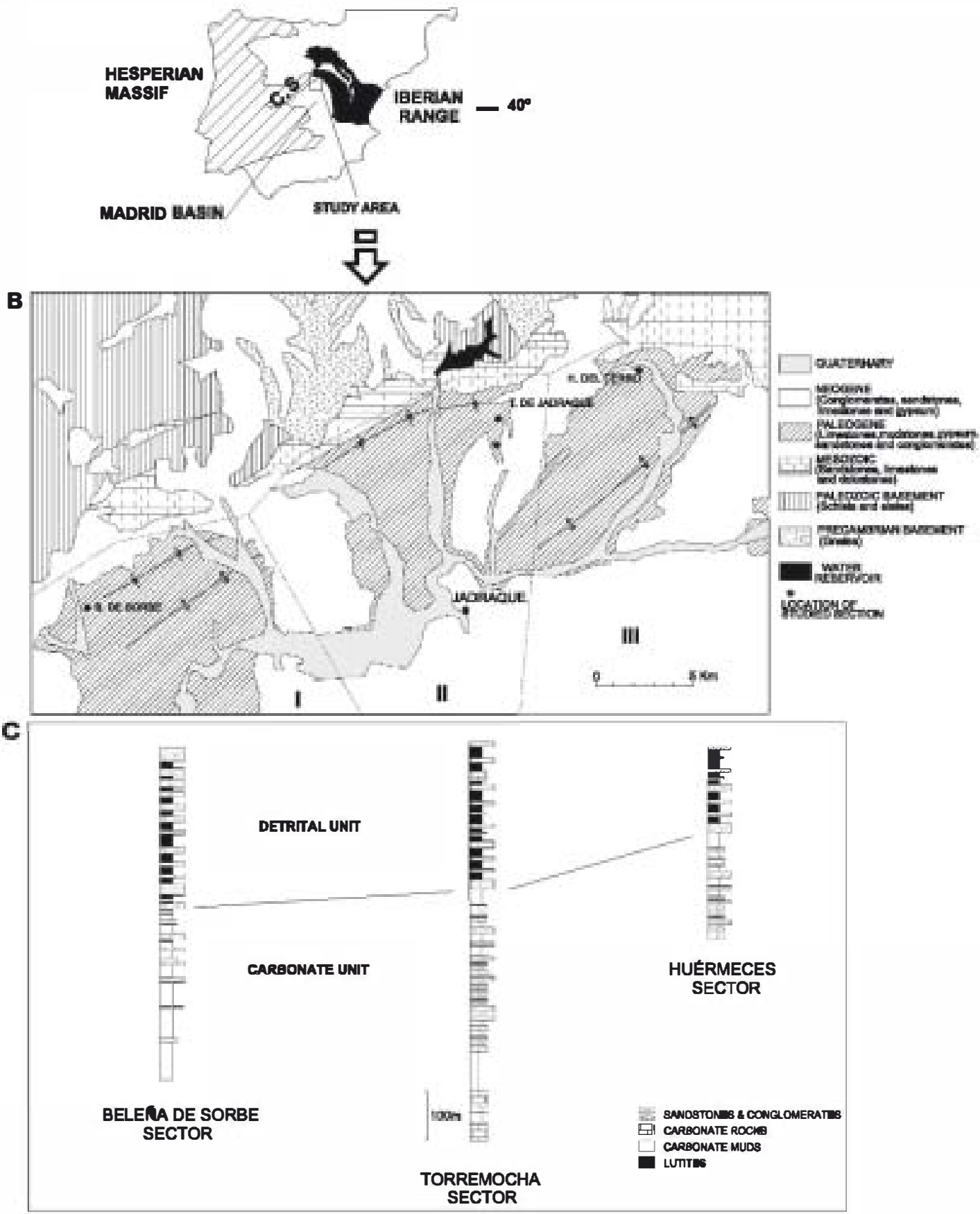

Fig. 1. Geological setting of the study area. (A) Distribution of the Hesperian Massif, Iberian Range and Madrid Basin in the Iberian Peninsula C.S., Central system. (B) Geological map of Palaeogene deposits and distribution of sectors: I-Beleña de Sorbe sector, II-Torremocha de Jadraque sector and III-Huérneces del Cerro sector. *Location of the studied stratigraphic section. (C) Cross-section of the three sectors. 


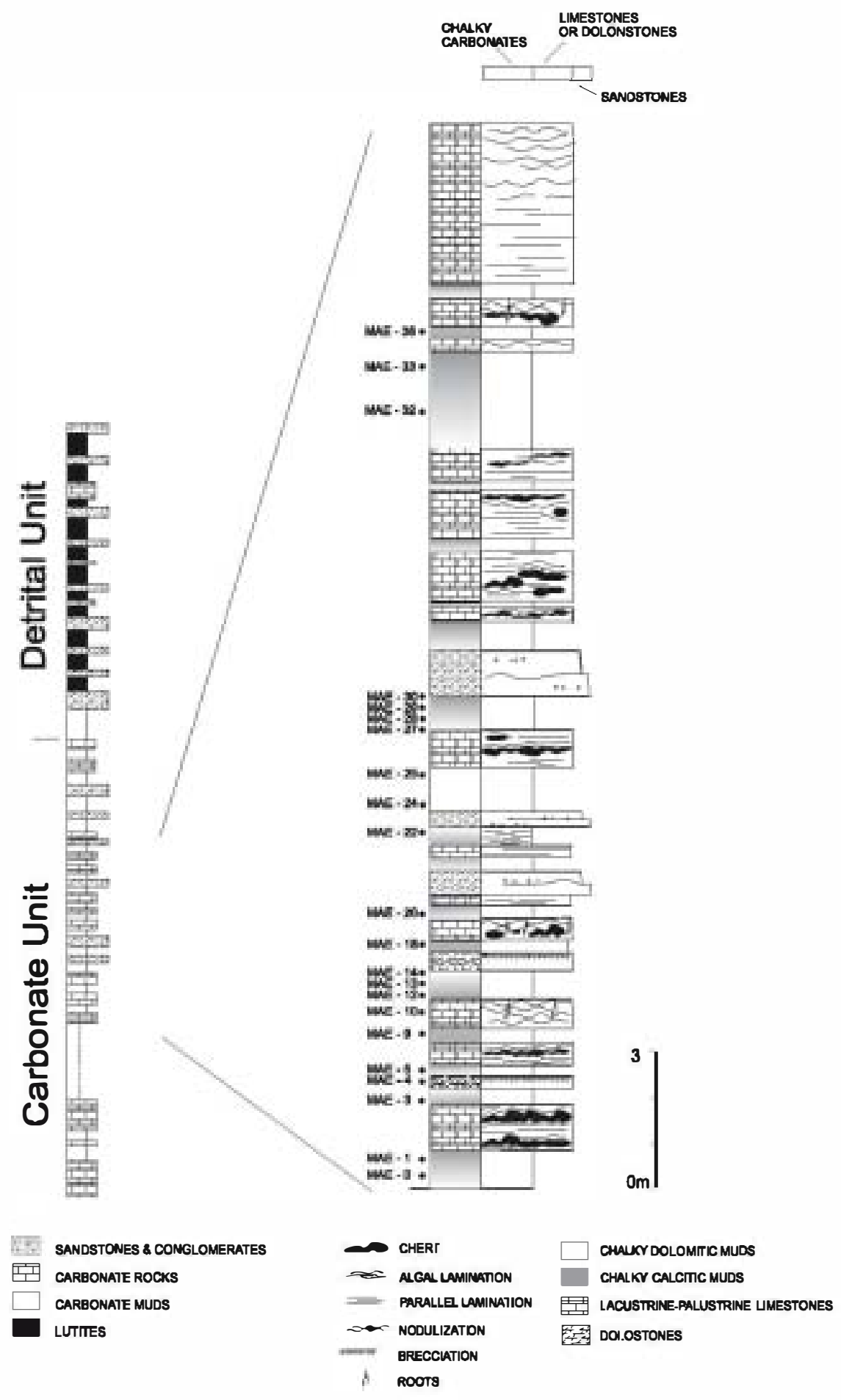

Fig. 2. General Palaeogene section and the local, studied section around Torremocha de Jadraque (from Bustillo et al., 2002). 
consists of lacustrine carbønate sediments (marls, laminate marls with terrigenous and marly limestones) with intercalated, upward-thickening sandstone sequences that are interpreted as lacustrine delta deposits (Arribas et al., 1983). Towards the eastern sectors (Huérmeces del Cerrø and Torremøcha de Jadraque), the Carbonate Unit shows highly developed palustrine and lacustrine facies. Several palustrine facies have been described in the Huérmeces del Cerrø sector where this unit is not as thick and pedogenesis was extensive. The Torremocha de Jadraque sector has more develøped lacustrine sedimentatiøn, reflected in its carbonate sediments over $500 \mathrm{~m}$ thick and the predominance of littoral and basinal facies (Arribas, 1986a,b). It is in this sector where several layers of chalky carbønates (very pure calcitic and dolomitic carbonates) appear forming the lower part of regressive lacustrine sequences (Fig. 2). Indurated lacustrine and palustrine limestones are interlaid with chalky carbonates, showing evidence of early diagenetic processes developed under arid-semiarid climate (Arribas, 1986a; Bustill• et al., 2002). C•n-

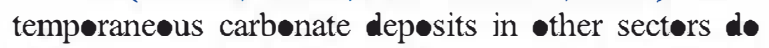
n॰t have this peculiar carbonate facies (Arribas, 1986a, b).

In the Palaeøene succession the burial depth could be estimated as $\mathbf{8 0 0} \mathrm{m}$ maximum, considering the total thickness of Palaeøene depøsits. Alsø, assuming a geothermal gradient between 25 and $30{ }^{\circ} \mathrm{C}$ for the intracratonic Madrid Basin (Tejerø and Ruiz, 2002), temperature values could be estimate as $30-4{ }^{\circ} \mathrm{C}$ during burial.

\section{Analytical methods}

The lacustrine chalky carbønates were sampled in the Torremøcha de Jadraque sector. Twenty-tw॰ samples were taken in order t॰ collect a diversity of types. The stratigraphic positions of the samples are shown in Fig. 2.

The mineralogy of the samples was determined using a Philips X-ray diffraction (XRD) system •perating at $40 \mathrm{kV}$ and $30 \mathrm{~mA}$ with møn॰chrømated $\mathrm{CuK}_{\alpha}$ radiation. The carbonate content of the samples was determined as the difference between the total sample and $\mathrm{HCl}$-inseluble residues. The relative amounts of calcite and dolomite were realized by XRD using calibration curves with known mixtures of both minerals and introducing halite as internal standard (Hardy and Tucker, 1988). The type of calcite, the proportion $\bullet \mathrm{CaCO}_{3}$ in dølømite, and the degree of ordering of the dolomite, were als determined by XRD (Hardy and Tucker, 1988).

P•larized light and scanning electron microscopy (SEM) were used to determine the petrological prøperties of the samples, including textures and mineral-gy. SEM was performed using a Philips KL-20 scanning electron microscope equipped with an energy dispersive X-ray analyser (EDAX-DX-4i). Fresh fracture surfaces of the samples were gold covered.

Majør and trace-element contents were calculated in individual calcite and dolomite crystals (1 $\mu \mathrm{m}$ in

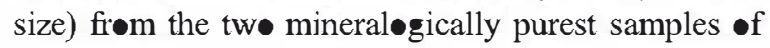
each chalky carbønate type using electron micrøprøbe analysis. Working on polished and carbon-coated surfaces, these analyses were performed with a JEOL electron micrøprobe (JXA $\mathbf{8 . 9 0 0 ~ M ) ~ e q u i p p e d ~ w i t h ~}$ four spectrometers at the L'niversidad Complutense de Madrid. Backscattere electron analysis was alsø performed. The standards used are described by Jarosewich et al. (1980) and were provided by the Department of Mineral Sciences of the Smithsønian Institution (Washington).

Petrophysical testing included grain density, dry bulk density, free water absørption and porøsity, following the recommendations of the International Society of Røck Mechanics (ISRM, 1979). It was not possible to determine the saturated density nor water absorption due the slaking of the samples in the presence of water. A durability test was performed to see whether there was any lack of crystal bonding due to chemical cementation. The one cycle slaking in water test (Lutton, 1977; Seedsman, 1986) followed methods used to assess the durability of shales. This invelved immersing dry samples in distille water to -bserve their disintegration mechanisms, and to estimate the extent of slaking. Slaking is the process thrøugh which a material (compacted but nøt cemented) disintegrates or crumbles int small particles $\bullet$ flakes when expøsed to møisture. The extent -f slaking in the presence of water, and the mechanisms by which it eccurs, depends on the mineral and chemical composition of the sample, the nature of the inter-crystal bonds, and the size of pores and permeability. After immersion in water, the rocks were 
-bserved continuously for $24 \mathrm{~h}$ and their disintegration monitored. Samples were recorded as having undergone complete breakdown, partial breakdown or n- change. The durability of the rock was estimated using the "jar slake index" (Ij), proposed by Lutton (1977). This gives a simple descriptive index for slaking behaviour. A six point classification scale is used to describe the observed behaviøur, ranging from 1 , in which the material degrades to a pile of flakes or mud, to 6 , in which no change is observed.

\section{Composition of the chalky carbonates}

\subsection{Mineralogy and petrology}

The most characteristic features of the chalky carbonates are their white colour and massive and disaggregated appearance. They form beds $0.5-1 \mathrm{~m}$ thick and comprise the lower layers of lacustrine regressive sequences (Fig. 2). These facies have been interprete as basinal lacustrine deposits formed in the areas farthest frøm the shøre (Bustill• et al., 2002).

Table 1 shows the bulk mineralegical compesition of the chalky carbønates. The carbønate fraction consists of calcite and dolømite of variable propørtiøns. Nøn-carbønate particles (clays and very fine quartz) form less than $15 \%$ of the rock volume. Two mineraløgical types of chalky carbønates can be define $\bullet n$ the basis of their mineraløgical compesition: chalky calcitic and chalky dolomitic muds.

The chalky calcitic muds contain more than $\mathbf{8 0 \%}$ calcite (løw Mg-calcite with 2-4 m॰l\% $\mathrm{MgCO}_{3}$, according to XRD data). These have a low clay mineral content $(<10 \%)$, mainly Al-smectite, illite and paly-

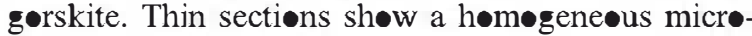
crystalline texture. Charophyte and ostracod fragments may be present in small quantities $(<2 \%)$. Under SEM

Table 1

Mineralogical composition and main physical properties of sampled Paleogene chalky carbonates

\begin{tabular}{|c|c|c|c|c|c|c|c|c|c|c|}
\hline \multirow[t]{2}{*}{ Samples } & \multicolumn{5}{|c|}{ Mineralogical composition } & \multicolumn{3}{|c|}{ Physical properties } & \multicolumn{2}{|c|}{ Stable isotopes } \\
\hline & MT & $\begin{array}{l}\text { C } \\
(\%)\end{array}$ & $\begin{array}{l}\mathbf{D} \\
(\%)\end{array}$ & $\begin{array}{l}\text { C-M } \\
(\%)\end{array}$ & $\begin{array}{l}\mathbf{Q} \\
(\%)\end{array}$ & DRY-D & GD & $\begin{array}{l}\mathrm{P} \\
(\%)\end{array}$ & $\delta^{13} \mathrm{C}$ & $\delta^{18} \bullet$ \\
\hline Mae-1 & $\mathrm{C}$ & 90 & 6 & 4 & - & 1.95 & 2.60 & 23 & & \\
\hline Mae-3 & $\mathrm{C}$ & 100 & $\bullet$ & - & - & 2.00 & 2.54 & 22 & -6.41 & -5.58 \\
\hline Mae-4 & $\mathbf{D}$ & 5 & 89 & 6 & - & $1.7 \bullet$ & 2.61 & 33 & -4.1 & -.65 \\
\hline Mae-9 & $\mathrm{C}$ & 87 & 5 & 7 & 1 & & & & & \\
\hline Mae-10 & $\mathrm{C}$ & 90 & 6 & 4 & - & 2.00 & 2.4 & 17 & & \\
\hline Mae-10 & $\mathrm{C}$ & 90 & 6 & 4 & - & 2.00 & 2.4 & 17 & & \\
\hline Mae-12 & $\mathrm{C}$ & 93 & 4 & 3 & - & 1.90 & & 17 & & \\
\hline Mae-13 & CD & 74 & 13 & 12 & 1 & 1.85 & 2.56 & 38 & & \\
\hline Mae-22 & $\mathrm{C} \boldsymbol{\nabla}$ & 31 & 39 & 9 & 21 & 2.10 & 2.63 & 20 & & \\
\hline Mae-24 & D & 3 & 84 & 12 & 1 & 1.95 & 2.62 & 25 & & \\
\hline Mae-25 & D & 3 & 84 & 12 & 1 & 1.95 & 2.61 & 25 & & \\
\hline Mae-27 & D & 1 & 80 & 17 & 2 & 2.00 & 2.63 & 24 & & \\
\hline Mae-28 & $\mathrm{C}$ & 82 & 6 & 12 & 0 & & 2.49 & 21 & & \\
\hline Mae-29 & $\mathrm{C}$ & 88 & 6 & 6 & 0 & 1.95 & 2.59 & 24 & & \\
\hline Mae-30 & $\mathbf{D}$ & 2 & 84 & 12 & 2 & & & & -4.37 & 1.24 \\
\hline Mae-32 & $\mathrm{C} \mathbf{D}$ & 50 & 31 & 13 & 6 & & 2.60 & 25 & & \\
\hline Mae-33 & $\mathrm{C}$ & 89 & $\bullet$ & 11 & - & & 2.56 & 24 & & \\
\hline Mae-36 & $\mathrm{C}$ & 96 & 0 & 4 & 0 & & 2.59 & 24 & -5.8 & -4.98 \\
\hline
\end{tabular}

MT, mineralogical types $(\mathrm{C}=$ chalky calcitic mud, $\mathbf{D}=$ chalky dolomitic mud $), \mathrm{C}=$ calcite, $\mathbf{D}=$ dolomite, $\mathrm{C}$-M $=$ clay minerals, $\mathbf{Q}=$ quartz, $\mathbf{D r y}$ $\mathbf{D}=$ dry bulk density $\left(\mathrm{g} / \mathrm{cm}^{3}\right), \mathrm{G}=$ grain density $\left(\mathrm{g} / \mathrm{cm}^{3}\right), \mathbf{P}=$ porosity $(\%)$. Stable isotopes data from Bustillo et al. (2002) 
examination, the size and shape of the calcite crystals is very variable, but most are less than $10 \mu \mathrm{m}$ in diameter (commonly 0.3-7 $\mu \mathrm{m}$ ) (Fig. 3A). The crystals are euhedral (rhømbic) and subeuhedral (Fig. 3A), sømetimes with a spherical or rounded appearance (Fig. 3B). The mosaic has a high intercrystalline porosity (Fig. $3 \mathrm{~A})$, but some locally show intracrystalline porøsity. In some places, the largest crystals (up to $25 \mu \mathrm{m}$ ) locally -ccur as calcitic cement (Fig. 3D). The surfaces of the crystals are covere by fibrous clay minerals such as phylløsilicate cement (Fig. 3C), which løcally appears as intercrystalline sheets (Fig. 3B). EDAX semi-quantitative analysis showed these fibrous clay minerals to have amounts (\% weight) of major oxides: $\mathrm{SiO}_{2}=$ $46.85, \mathrm{Al}_{2} \mathbf{O}_{3}=12.75$ and $\mathbf{M g}=12.21$, that agree with the chemical compesition of palygorskite (Weaver and P॰llard, 1973) and with their presence found by XRD.

The chalky dolomitic muds contain more than $\mathbf{8 0 \%}$ dolømite. According to XRD data, this is almost stoichiometric (with 49.00-50.65 mø1\% $\mathrm{CaCO}_{3}$ ) and pøorly ordered, considering the values $(0.37-0.54)$ btaine by the relative intensities of the 015 peak and 110 peak (Hardy and Tucker, 1988). The highest ordering values correspond to samples with a significant quantity of extrabasinal dolømitic grains, which show spheroidal shapes and corroded surfaces (Fig. 4D). Their clay mineral content includes illite, Alsmectite and palygorskite $(10-15 \%)$. Thin sections show a homøgeneous microcrystalline texture. Skeletal grains are not present. Under SEM examination, the pure dolomitic muds appear to be made of small euhedral dolømite rhombohedra $<7 \mu \mathrm{m}$ in size (Fig. 4A). The large calcite crystals can enclose small euhedral dølømite crystals as a consequence of løcal calcitic cementation, but this is not a volumetrically impertant precess. Palygerskite eccurs on the crystal edges and the faces of euhedral dølømite rhømb hedra (Fig. 4A and B) and locally as dense aggregates asseciated with the edges of illite and smectite laminae (Bustillø et al., 1998). Chalky dolømitic
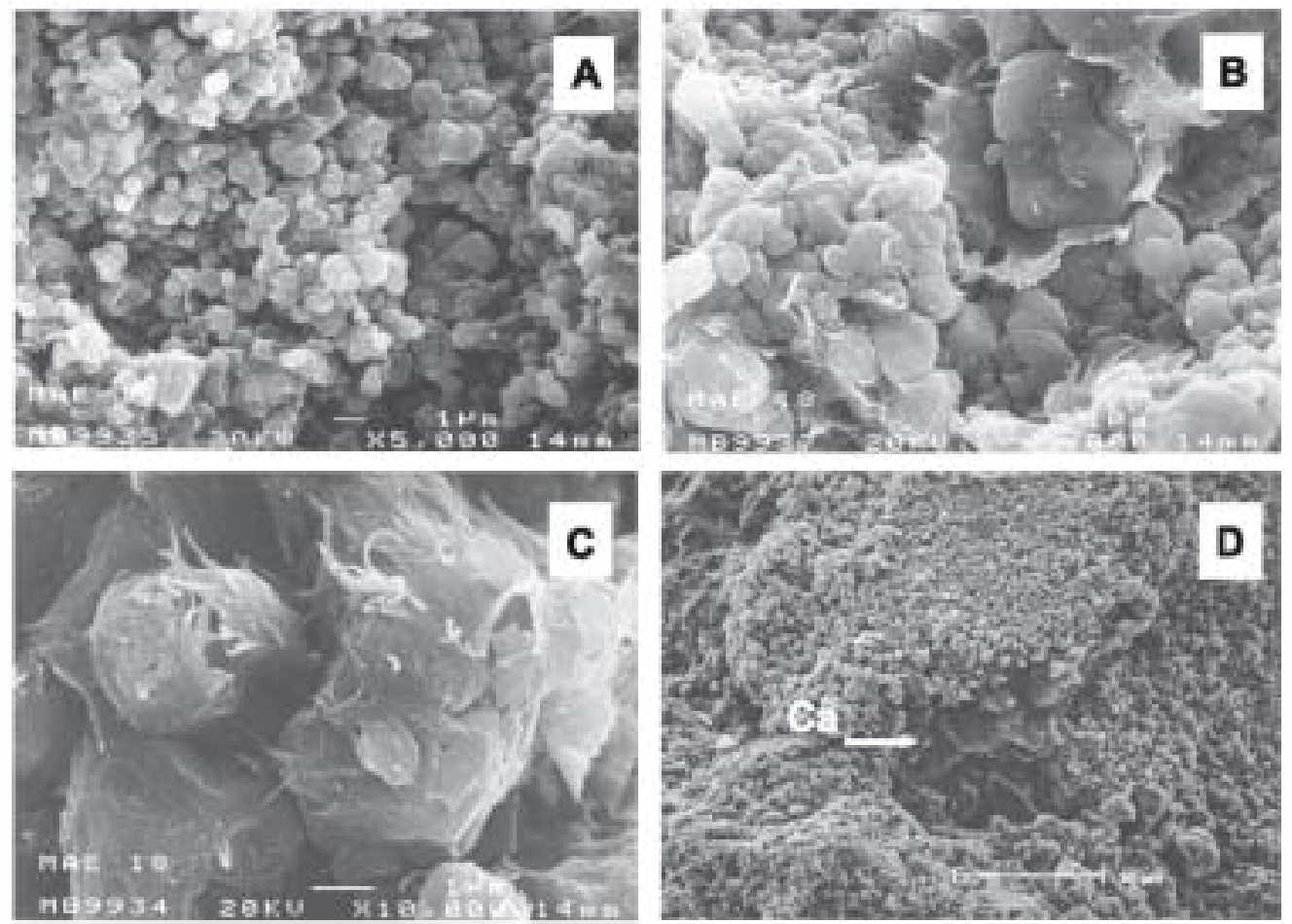

Fig. 3. SEM pictures of chalky calcitic muds. (A) Mosaic of calcite crystals with high porosity due to macro- and micropores. The size and shape of the calcite crystals are variable. (B) Some of the crystals are rounded; fibrous crystals entirely covered by palygorskite. (D) General view of the chalky calcitic mud with large calcite crystals as local cement. 

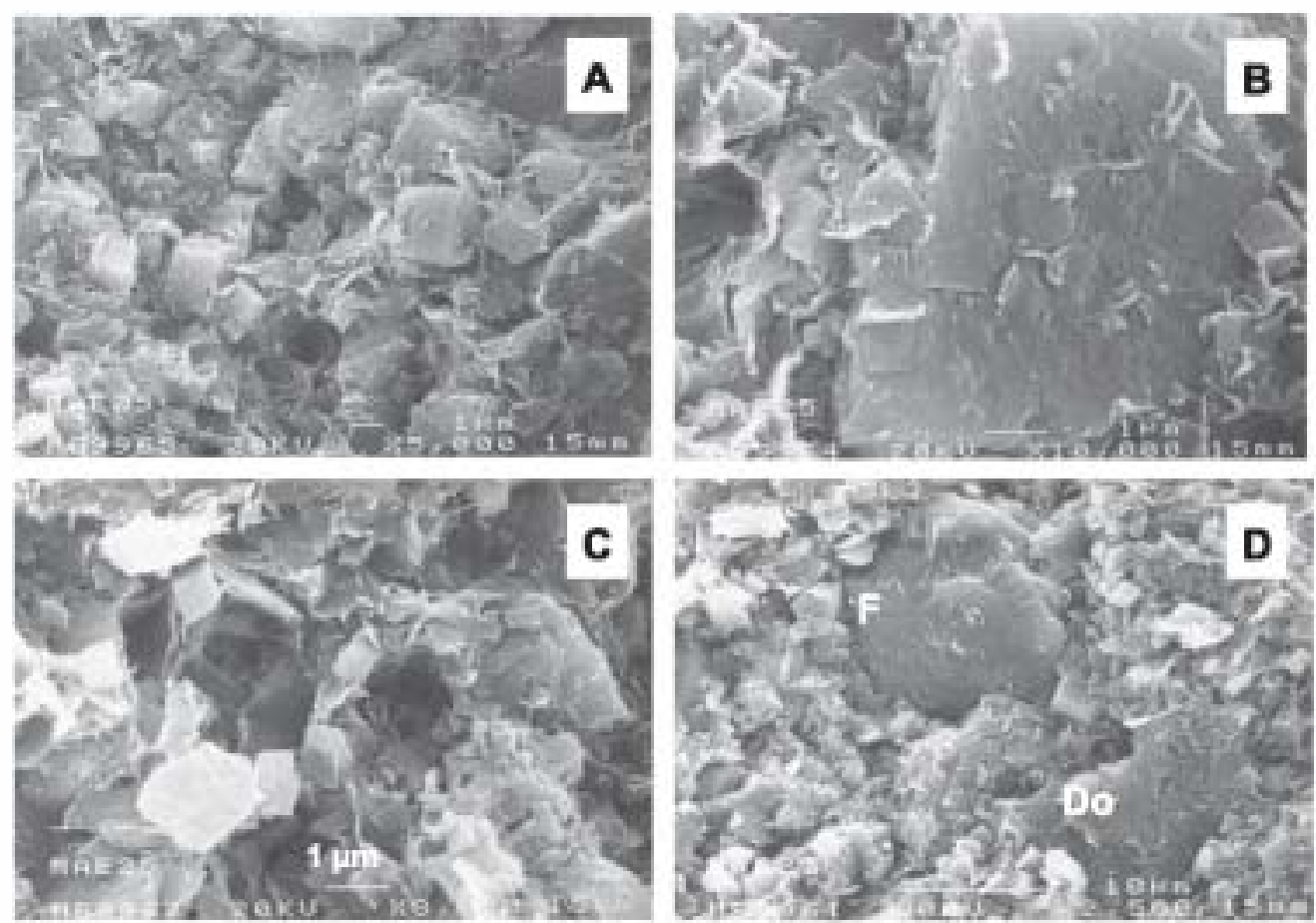

Fig. 4. SEM pictures of chalky dolomitic muds. (A) Mosaic of euhedral dolomite crystals with intercrystalline porosity and palygorskite cement. (B) Close-up of the dolomite crystals showing palygorskite fibres on their faces. (C) Dissolution of the dolomite crystals gave rise to moulds between the palygorskite sheets. (D) Dolomitic grain (Do) showing corrosion on the surface. (F) A feldspar grain appears as extrabasinal grain.

muds shøw great intercrystalline porøsity (Fig. 4A); less frequently they als show intracrystalline porosity. The total dissolution of the carbønate crystals covered with palygorskite sheets caused a secondary moldic poresity (Fig. 4C). Where chalky dolomitic muds are overlain by lacustrine sandstones, high percentages of extrabasinal dolomite and other grains are seen, all $\bullet$ which show signs of corrosion and dissølution (Fig. 4D).

Some samples show intermediate mixtures of calcite and dolømite, but generally there is more of the former than the latter (Table 1). Under SEM examination, anhedral and rounde calcite crystals appear mixed with dolomite crystals in a random distribution and with intercrystalline porøsity (Figs. 5A-D). The rounded calcite crystals are probably relics of the primary calcitic muds, affected by dissolution. The dolømite crystals appear as euhedral rhombøhedra similar to those described in the chalky dolomitic muds. Some show intracrystalline and moldic poresity
(Fig. 5A and B). Palygorskite is very commøn, covering the carbonate crystals or forming sheets between them (Fig. 5D). Lecally, palygorskite als• appears in sheets asseciated with smectites and as isølated aggregates that sometimes include small, rhombic dolømite crystals.

\subsection{Geochemistry}

The electrøn micrøprøbe data $\bullet$ is lated crystals $\bullet$ calcite and dolømite from the mineraløgically purest samples (Mae-18, calcite; Mae-4, dolomite) together with the percentages in the different types of carbnates are summarized in Table 2 . The chalky carbnates showe small quantities of alumina and silica due to the presence of clay minerals between carbonate crystals. The impossibility of separating the clays from the carbonate crystals led to small readings for alumina and silica in the microprobe analysis of is late carbonate crystals. Is topic data of these 

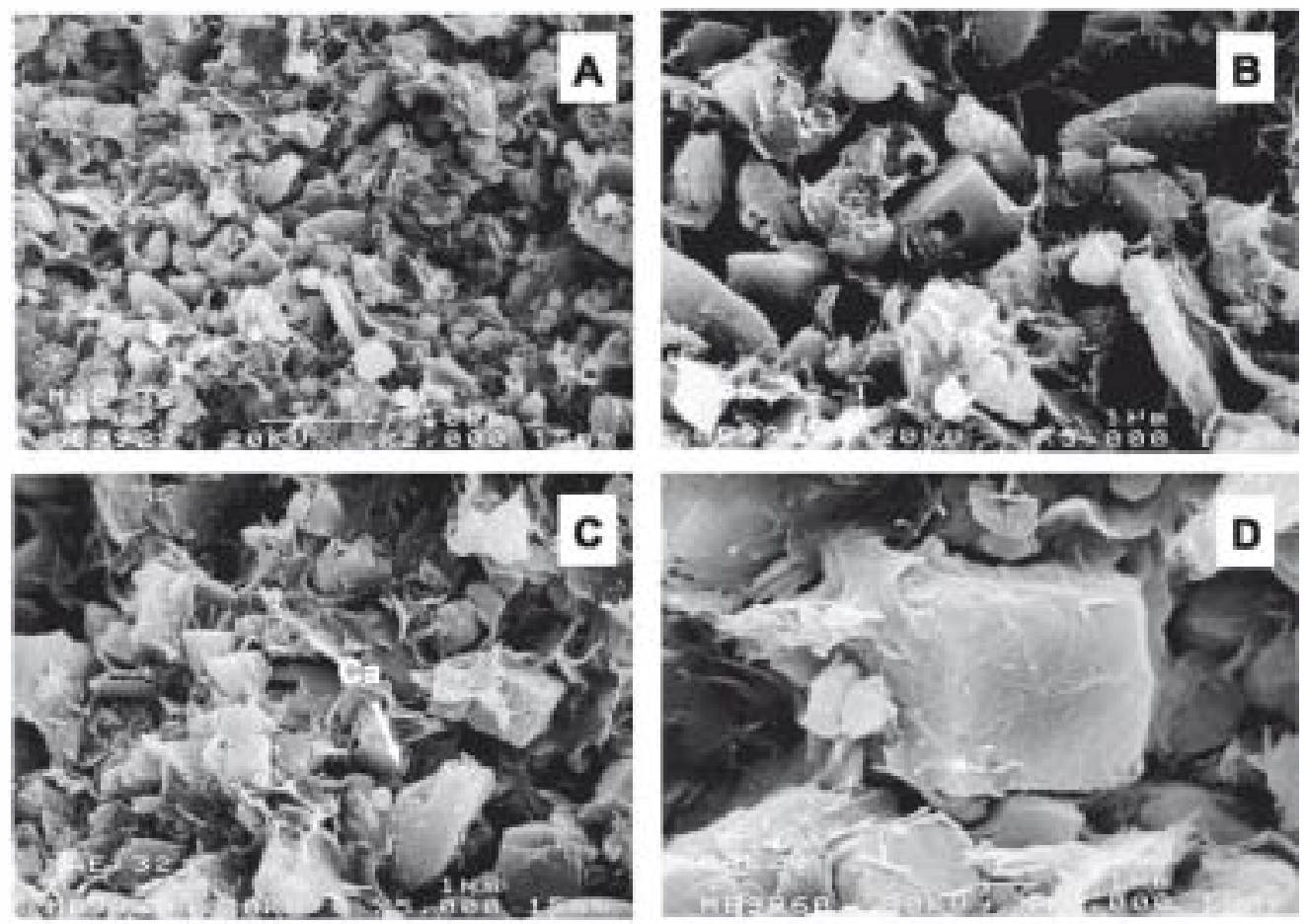

Fig. 5. SEM pictures of chalky calcitic-dolomitic muds. (A) General view of a chalky calcitic-dolomitic mud with intercrystalline, moldic (arrow) and in racrystalline porosity. (B) Close-up of the intracrystalline microporosity. (C) The calcite crystals are distinguished from the dolomite crystals by their rounded and anhedral shapes. (D) Palygorskite cementing and covering the carbonate crystals.

samples come from Bustillø et al. (2002) and are shown in Table 1.

The chemical composition of the chalky calcitic muds is very homogeneous and corresponds to low $\mathrm{Mg}$-calcite with $<2 \%$ mole $\mathrm{MgCO}_{3}$ (Table 2). Contents in Sr $($ mean $=411 \mathrm{ppm}), \mathrm{Mn}($ mean $=178 \mathrm{ppm})$ and $\mathrm{Fe}(\mathrm{mean}=235 \mathrm{ppm})$ are low but variable (Table 2). These values are similar t॰ $\bullet$ ther lacustrine carb nates (Tlig, 1987; Wright et al., 1997), indicating oxygenated and non-saline continental water. For the other hand, Mn and Fe contents are low compared with these propesed by Veizer (1983) for a theoretical average composition of a meteoric diagenetic lowMagnesian calcite.

In the chalky dolomitic muds, the mol\% $\mathrm{CaCO}_{3}$ values estimate from the micropr be analysis data vary between $\mathbf{4 8 . 9 \%}$ and $50.5 \%$ (Table 2 ), indicating that the dolomite is nearly stoichiometric. Mn $(<217$ when $\mathrm{Mn}$ was detected) and $\mathrm{Fe}$ (mean $=595 \mathrm{ppm})$ contents are low and very variable as $\bullet c c u r$ in chalkycalcitic muds (Table 2 ). Sr contents ( $<262$ ppm when
Sr was detected) are very low, but similar to those estimate by Tlig (1987) in dolomites formed in lacustrine environments under meteoric water influence. García del Cura et al. (2001) give values slightly higher in $\mathrm{Sr}($ mean $=655 \mathrm{ppm})$ in lacustrine dolomites.

\section{Physical properties}

\subsection{Microfabric}

The studied samples are relatively søft, friable and easily eroded but show cohesion. Most of the chalky carbønate poresity is intercrystalline in origin (Figs. $3-5)$; therefore, water transmission is through the body of the chalky carbonates rather than along sølution charmels. SEM analysis shows that the shape and size of the intercrystalline pores in the samples are not homøgeneous. Porøsity varies between 10 $40 \%$ (Table 1) and corresponds to micrø and macre- 


\begin{tabular}{|c|c|c|c|c|c|c|c|c|c|c|c|}
\hline $\begin{array}{l}\text { Calcitic } \\
\text { mud }\end{array}$ & Mae18-1 & Mae18-2 & Mae18-3 & Mae18-4 & Mae18-5 & Mae18-6 & Mae18-7 & Mae18-8 & Mae18-9 & Mean & \\
\hline $\mathrm{Ca}(\%)$ & 51,267 & 51,735 & 50,941 & $5 \bullet, 934$ & 50,894 & 51,745 & 51,243 & 51,079 & 52,106 & 51,327 & \\
\hline $\operatorname{Mg}(\%)$ & 0.483 & 0.458 & 0.469 & 0.579 & 0.717 & 0.380 & 0.416 & 0.449 & 0.479 & 0.492 & \\
\hline $\mathrm{SiO}_{2}(\%)$ & $\bullet .151$ & 0.032 & 0.344 & 0.252 & 0.14 & $\bullet .131$ & 0.161 & 0.091 & $\bullet .061$ & 0.151 & \\
\hline $\mathrm{Al}_{2} \boldsymbol{\Theta}_{3}(\%)$ & 0.013 & 0.001 & 0.113 & 0.009 & - & 0.03 & 0.037 & 0.019 & 0.011 & 0.029 & \\
\hline $\mathrm{Fe}(\mathrm{ppm})$ & 194 & 319 & 218 & 194 & 70 & 606 & - & 47 & - & 235 & \\
\hline \multicolumn{12}{|c|}{$\%$ Carbonates } \\
\hline $\mathrm{CaCO}_{3}$ & 98,646 & 98,690 & 98,589 & 98,333 & 97,975 & 98,775 & 98,804 & 98,716 & 98,684 & 98,579 & \\
\hline $\mathrm{MgCO}_{3}$ & 1295 & 1215 & 1262 & 1554 & 1920 & 1011 & 1117 & 1209 & 1261 & 0.013 & \\
\hline $\mathrm{MnC}_{3}$ & 0.000 & 0.000 & 0.089 & 0.000 & 0.000 & 0.000 & 0.010 & 0.000 & 0.005 & $\bullet .012$ & \\
\hline $\mathrm{Ca}(\%)$ & 28,579 & 28,647 & 28,052 & 28,407 & 30,478 & 29,065 & 29,477 & 29,333 & 28,951 & 28,902 & 28,989 \\
\hline $\operatorname{Mg}(\%)$ & 20,037 & 20,252 & 20,807 & 20,633 & $21,4 \bullet 3$ & 20,951 & 21,008 & 21,365 & 20,698 & $21,61 \bullet$ & 20,876 \\
\hline $\mathrm{SiO}_{2}(\%)$ & 0.147 & 0.384 & 0.318 & 0.306 & 0.058 & 0.662 & 0.257 & 0.314 & 1,048 & 0.676 & 0.417 \\
\hline $\mathrm{Al}_{2} \bigcirc(\%)$ & 0.101 & 0.191 & 0.104 & 0.118 & 0.028 & 0.310 & 0.123 & 0.095 & 0.397 & 0.251 & 0.171 \\
\hline $\mathrm{Fe}(\mathrm{ppm})$ & 1213 & 233 & 295 & 653 & 319 & 948 & 199 & 902 & 801 & 389 & 595 \\
\hline Mn (ppm) & - & - & - & 186 & 217 & 132 & 23 & - & - & 108 & 111 \\
\hline $\mathrm{Sr}(\mathrm{ppm})$ & 178 & - & 237 & 211 & 51 & - & - & 262 & - & - & 188 \\
\hline \multicolumn{12}{|c|}{$\%$ Carbonates } \\
\hline $\mathrm{CaC}_{3}$ & $5 \bullet, 5 \bullet 3$ & 50,391 & 49,177 & 49,653 & 50,536 & 49,836 & $5 \bullet, \bullet 41$ & 49,580 & 50,065 & 48,972 & 49,875 \\
\hline
\end{tabular}

Values below the detection limit (-).

pørøsity. Micrøp॰res, with an average size of arøund $2 \mu \mathrm{m}$, are rounded except where they result from the total dissolution of the crystals. Microporesity is around $70 \%$ of the total porosity. Macropores (2$20 \mu \mathrm{m}$ ) represent around $20 \%$ of the total poresity and are more irregular in size and shape. Løcally, larger pores $>\mathbf{2 0} \mu \mathrm{m}$ are alsø encountered between the larger calcite and dolomite crystals $(>80 \mu \mathrm{m})$. Clay minerals partially fill the original poresity of the chalky carbonates and play an important role in controlling the final porosity of these sediments. Clays als give a medium-tø-high cohesion to the chalky carbønates due to clay bønding. However, the lack of a significant carbønate cementation renders these rocks friable.

\subsection{Grain density, dry bulk density and porosity}

D॰minant physical properties of the studied chalky carbønates are their very low dry bulk density (1.62.2) $\mathrm{g} / \mathrm{cm}^{3}$ and medium to relatively high porosity $(10-40 \%$; Table 1). These values are typical of low to medium compacted materials. The absølute values $\bullet$ the dry bulk density obtained here are very low compare to materials with similar percentage porøsities (Table 1). The relationship between dry bulk density and percentage total porosity is shown in Fig. 6A. The expected negative linear correlation between dry bulk density and porøsity is seen, except in the case of the medium dense samples $\left(2.0 \mathrm{~g} / \mathrm{cm}^{3}\right)$ where there is a large variation in porosity. 
A

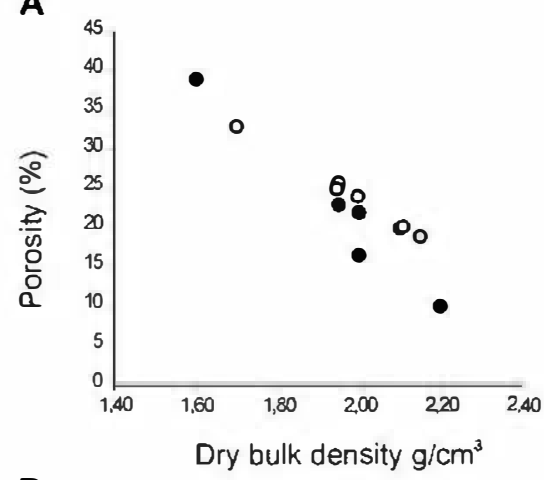

B

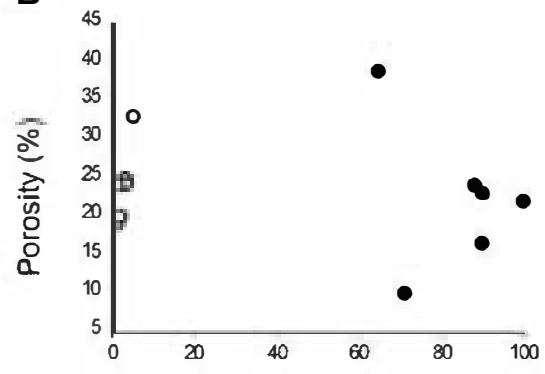

Calcite \%

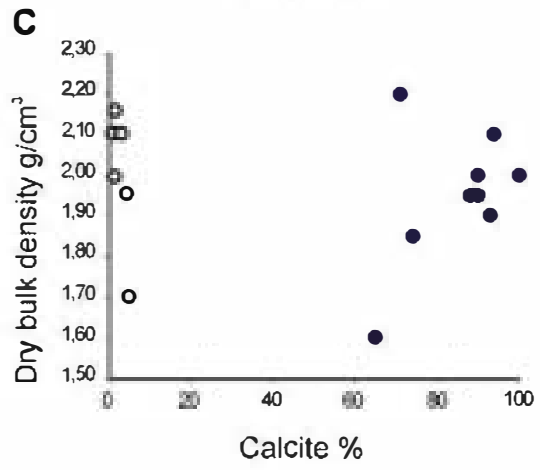

Fig. 6. Relationship between porosity and the bulk grain density (A) and their relationship with calcite content (B and C). Black circles $=$ chalky calcitic muds and white circles $=$ chalky dolomitic muds.

The grain density is almost constant, the mean of $2.62 \mathrm{~g} / \mathrm{cm}^{3}$ being independent of the mineralogical composition of the carbonates in the sample (Table 1). These values are very low compared to those of typical limestones or dolomites, which normally have an average grain density of $2.70-2.80$ and over $2.9 \mathrm{~g} /$ $\mathrm{cm}^{3}$, respectively.

T• detect any relationship between mineraløgical compesition and variation in these physical prøper- ties, the percentage of calcite in the samples was plotted against porosity and dry bulk density (Fig. 6B and $C$, respectively). The graphs show no clear evidence of any systematic relationship between calcite content and these properties. However, it can be seen that the chalky dolomitic muds generally have a somewhat higher dry bulk density than the chalky calcitic muds.

The chalky calcitic muds ( $>60 \%$ calcite content) show the largest variation values in dry bulk density and poresity (minimum: $1.6 \mathrm{~g} / \mathrm{cm}^{3}$ and $10 \%$; maximum: $2.2 \mathrm{~g} / \mathrm{cm}^{3}$ and $40 \%$, respectively). This, plus the weak correlation between the calcite content and physical properties, shows the influence of other factors such as: (i) the variable content of fibrous

Table 3

Results of the slaking test in water

\begin{tabular}{|c|c|c|c|c|}
\hline Sample & $\begin{array}{l}\mathrm{CCl} \\
\mathrm{CM}\end{array}$ & Slaking time & $\begin{array}{l}\text { Lutton } \\
\text { Index }\end{array}$ & Remarks \\
\hline Mae-@ & $88 / 9$ & $4-6 h$ & - & $\begin{array}{l}\text { Completely breaks } \\
\text { down }\end{array}$ \\
\hline Mae-l & $96 / 4$ & $10-15 \min$ & $\bullet$ & $\begin{array}{l}\text { Completely breaks } \\
\text { down }\end{array}$ \\
\hline Mae-4 & $94 / 6$ & $\begin{array}{l}\text { Partial slaking } \\
\text { in } 24 \mathrm{~h}\end{array}$ & 1 & $\begin{array}{l}\text { About one third of } \\
\text { the material is } \\
\text { reduced to very } \\
\text { small pieces }\end{array}$ \\
\hline Mae-5 & $94 / 6$ & $15-20 \mathrm{~min}$ & 0 & $\begin{array}{l}\text { Completely breaks } \\
\text { down }\end{array}$ \\
\hline Mae-10 & $96 / 4$ & $\begin{array}{l}\text { Partial slaking } \\
\text { in } 24 \mathrm{~h}\end{array}$ & 1 & $\begin{array}{l}\text { About one third of } \\
\text { the material is } \\
\text { reduced to very } \\
\text { small pieces }\end{array}$ \\
\hline Mae-20 & $81 / 6$ & $20-30 \mathrm{~min}$ & 0 & $\begin{array}{l}\text { Completely breaks } \\
\text { down }\end{array}$ \\
\hline Mae-22 & $70 / 9$ & $4-6 h$ & 0 & $\begin{array}{l}\text { Completely breaks } \\
\text { down }\end{array}$ \\
\hline Mae-24 & $87 / 12$ & $10-15 \min$ & - & $\begin{array}{l}\text { Completely breaks } \\
\text { down }\end{array}$ \\
\hline Mae-29 & $94 / 6$ & $24 \mathrm{~h}$ & 2 & $\begin{array}{l}\text { About three fourths } \\
\text { of the material is } \\
\text { reduced to very } \\
\text { small pieces }\end{array}$ \\
\hline $\mathrm{Me}-30$ & $86 / 12$ & $4-6 h$ & - & $\begin{array}{l}\text { Completely breaks } \\
\text { down to small pieces }\end{array}$ \\
\hline Me-36 & $96 / 4$ & $24 \mathrm{~h}$ & 2 & $\begin{array}{l}\text { About three fourths } \\
\text { of the material is } \\
\text { reduced to very } \\
\text { small pieces }\end{array}$ \\
\hline
\end{tabular}

$\overline{\mathrm{CC} / \mathrm{CM} \text { : relation between carbonate content }(\%) \text { and clay minerals }}$ content $(\%)$; Lutton Index (-1-2). 
clay minerals (which have a lower grain density) binding the carbonate crystals and (ii) the presence -f an important quantity of irregularly distributed intracrystalline poresity (as observed under the scanning electron microscope). The presence of the latter affects the abselute density (both the dry bulk density and grain density) but not the percentage porosity defined as the relationship between mass and volume. This is because the grain density of hollow crystals cannot be determined by common laboratory tests, and it is less than that of nondiss $\bullet$ lved crystals.

The slaking of the samples was alsø studied (Table 3). The chalky carbonates showed high levels of slaking and dispersion, with "jar slake index" ( $\mathrm{Ij}$, Lutton, 1977) values of between 0 and 2 (Table 3 ). After $1 \mathrm{~h}$ of immersion in the distilled water, the majority of the samples (except two) crumbled to form coarse-grained heaps and some dispersed, finer material at the bottom of the beaker. Complete break-

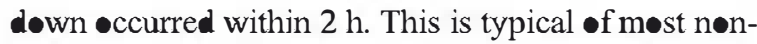
cemented sediments such as muds, marls or clay shales (Wood and Deø, 1975; Seedsman, 1986; Dick and Shakeor, 1992).

On the basis of the results, the chalky carbonates can be classified as non- durable "søil-like" materials (Lutton, 1977), when they degrade rapidly with complete disruption of the original structure of the rock. One reason for this may be related to the failure in tension between the particles due the compression - trapped air inside the small pores between the crystals. As indicated by Terzaghi and Peck (1967), this is one of the main reasons for the slaking (disaggregation) of most sediments with small pores. In the studied samples, the micropores made up almost $70 \%$ of the total poresity. However, it may als $\bullet$ be related to the løss of clay bonds by clay-water reactions, during the wetting and drying process. As -bserved with SEM, clay minerals are the main connectors between the calcite and dolomite crystals (Figs. 3-5). Once these bonds are broken, the calcite and dolomite crystals and the clays are free to disperse. The quantity of clay minerals detecte by XRD may not seem important, but many of them are fibrøus and, though scarce, are uniformly distributed. They -ccur at all contacts between calcite and dolomite crystals, with crystal-clay-crystal being the main interaction.

\section{Discussion}

These Palaengene chalky carbønates have withstood a cover of more than $800 \mathrm{~m}$ of sediments withøut significant diagenetic processes •ccurring. They alsø show high porosity (Table 1). The origin and the sedimentary processes involved in the accumulation of carbønate muds, their original mineraløgical composition and their diagenetic history can help explain their particular physical properties.

\subsection{Origin of the carbonate muds}

Bustillø et al. (2002) interpreted these depesits as being an inorganic carbonate sediment due to the absence of skeletal debris. But $\bullet$ ther possibilities exist such as the accumulation of fine detrital particles or biø-induce precipitation. Kelts and Hsü (1978) indicated the importance of detrital carbonates in the bulk of lacustrine marls and chalks, and the difficulty in distinguishing between primary and detrital lacustrine carbønate. Carbønates precipitate in freshwater lakes commonly have very negative $\delta^{13} \mathrm{C}$ and $\delta^{18} \mathrm{values,}$ which may permit the detrital component to be estimated (Kelts and Hsü, 1978). Isotøpic analyses of the studied chalky carbonates suggests that these carbonates precipitated in equilibrium with is ly light meteoric waters (Bustille et al., 2002; Table 1). Locally the high $\delta^{18}$ values in some chalky dolomitic muds (Table 1, Mae-4 and Mae-14) may be explained by the early formation of dolømite from water more enriched in heavy isotopes and increased evaporation in the sedimentation area (Bustillø et al., 2002). Thus, most of chalky carbonate muds probably formed in situ in the basinal areas of the lake as the result of inorganic calcite precipitation from supersaturated lake water. The origin would be similar to the abiotic whitings of calcite triggered by bi-mediated coccoid algal bløoms or evaporative concentration described by Wet et al. (2002) in lacustrine chalks. Seasonal whitings in lakes have been documented in ancient and modern lakes (Müller and Wagner, 1978; Platt and Wright, 1991). In søme modern lacustrine dolømite sediments, bacterial mørphøløgies in carbønate crystals have been described providing evidence that dolomite growth was influenced by microbial activity (Vasconcelos and McKenzie, 1997; García del Cura et al., 2001; Sánz-Mønter• et al., 2003). In 
the studied muds, scanning electron micrøgraphs shøw mosaics of euhedral (rhømbic) to subhedral crystals (both calcite or dølømite) with n॰ direct evidence of organic features (Figs. 3-5).

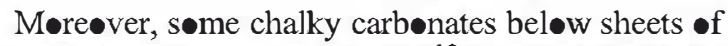
lacustrine sandstones had high $\delta^{18}$ values (Table 1 , Mae-20 and Mae-30), which may possibly be due to detrital input from the Mesøzic carbonates of the Iberian Range. There is evidence of alluvial reactivation of the adjacent fan systems, as demonstrated by the presence of sheet-flood and debris-flow deposits in both the Beleña de Sorbe and Torremocha de Jadraque sectors (Arribas, 1986a). As a consequence, extrabasinal carbønate components, together with littoral calcareous mud (composed of very finely char-phyte debris, <10 $\mu \mathrm{m}$ ), would have been deposited in the most distal areas $\bullet$ the shore lake. As $\bullet c c u r s$ in some marine chalks a rapid sedimentation and resedimentation by turbidity currents may have developed a porous calcareous sediment with little early cementation, whereas slow sedimentation rates together with much bioturbation and bottom current activity may facilitate early cementation and loss of porısity (Tucker and Wright, 1990).

The accumulation of calcareous muds in the basinal areas of the lake would be very rapid and would have preserved the high porosity of the original sediment. The sedimentation of these muds contrasts with the lacustrine dynamics in the littoral and supralittoral areas where active biøgenic carbonate production, together with the develøpment of an early meteric diagenesis (cementation and recrystallization), contributed to consølidated lacustrine limestones (Arribas, 1986a).

\subsection{Original mineralogy and pore fluid composition}

The chalky carbonate muds formed under distinct geochemical conditions. The textural, chemical and mineralogical characteristics suggest that the chalky calcitic muds probably precipitated as low Mg-calcite $\left(<2 \mathrm{m \bullet 1 \%} \mathrm{MgCO}_{3}\right.$ ) from løw salinity fresh water, as

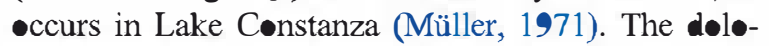
mite appears to have originated by early diagenetic replacement as suggested by the presence of micrørhombic crystals, near stoichiometry and poor order according to X-ray values (Gunatilaka, 1990; Last, 1990). This replacement may have occurred via a high Mg-calcite precursor mud since this is dolømitized in preference to low Mg-calcite mud, as •ccurs in the recent lacustrine sediments of Central Spain described by Yébenes et al. (1973). In the present case, high intercrystalline and intracrystalline porosity could be associate with a possible replacement precess, as eccurs in the lacustrine micrites described by Wright et al. (1997). The formation of high Mgcalcite lacustrine muds can be a consequence of chemical changes in lake water due to increased evaporation and raised salinity, or an increase in the Mg/Ca rati• (Müller et al., 1972; Kelts and Hsü, 1978). Müller et al. (1972) propøsed a "dynamic “ model to explain the formation of calcite and dolomite in the same sequence, in which extreme fluctuations of the $\mathrm{Mg} / \mathrm{Ca}$ rati are the most important factor. In the present case, the cyclic increase in the $\mathrm{Mg} / \mathrm{Ca}$ rati of the lake waters would be assøciated with the input of $\mathrm{Mg}^{2+}$ derived from the weathering - Mesøzic carbønates in the source area, and with an important development of palae søls in the supralittoral areas (Huérmeces del Cerrø sector, Arribas, 1986a) and the subsequent loss of $\mathrm{Ca}$ ions. In this sedimentological model, the composition of lacustrine water changed periodically from slightly magnesian $(\mathrm{Mg} / \mathrm{Ca}<2)$ to magnesian $(\mathrm{Mg} / \mathrm{Ca}$ between 2 and 12, Müller et al., 1972), resulting in calcitic or dolomitic muds formation respectively.

The original stable mineralogy (løw Mg-calcite and dolomite) of these chalky carbonates would have induce a very low diagenetic potential (Schölle, 1977). According to Moore (2001), the stable mineraløy at the time of burial is one of the most impertant factors that retards chemical compaction.

\subsection{The importance of clay minerals}

The chalky carbonates contain clay minerals such as illite, smectite, and palygorskite (Bustill• et al., 1998). According to SEM observations, the most volumetrically impertant is palygorskite. The XRD results probably reveal smaller amounts of palygorskite than actually exist, because the quantitative analysis is based on peak area. Ouhadi and Yong (2003) worked in several artificial mixtures of palygorskite and calcite and found that this quantitative analysis underestimates the presence of palygorskite and overestimates the presence of calcite. 
According to SEM •bservations, palygorskite appears widely dispersed through the chalky carbnates (Figs. 3-5). Palygorskite fibres coat the carbonate crystals, cement pores and build aggregates locally with $\mathrm{Al}$-smectite or illite.

Tw main origins for palygorskite have been proposed in the literature: inheritance or by authigenesis. In hot, arid regions palygorskite can be transported by alluvial or ae lian process from the søurces areas and be incorporated inte sediment as a detrital component (Verrechia and Le Coustumer, 1996). The detrital origin is rejected because in the lutites that $\bullet c c u r$ in fløodplains related laterally to the lacustrine carbønates $\bullet$ nly smectite and illite appear, not palygorskite (Arribas, 1985). On the other hand, palygerskite authigenesis can be explained by twe process (Verrechia and Le Coustumer, 1996; Worden and Morad, 2003): (1) alteration of pre-existing phyllosilicate minerals (such as mica and smectites) and then transformation int palygorskite and (2) precipitation from hypersaline pore waters.

The aggregates of palygorskite with Al-smectite or illite, $\bullet$ bserved under SEM, indicate that the original clay assemblage was mildly to strongly transformed int palygerskite. But palygorskite fibres alsø coat the carbonate crystals and it is probably formed during early diagenesis because they form the network of the secondary porøsity (Fig. 4C). Micrøporısity and the texture of silt-size carbonate provided additional appropriate conditions for early palygorskite precipitation (Verrechia and Le Coustumer, 1996). The high silica content of the waters, evidenced by chert and -paline nodules of the interlayered limestones (Fig. 2; Bustill et al., 2002), favoured the early diagenetic formation of the palygorskite from a detrital clay minerals precursor which provided the necessary aluminium. The high content in $\mathbf{M g}$ in the pore waters is linke to the compesition of the source areas (dølestones), the formation of calcimørphic paleosøls in close by supralitteral areas and als to the partial disselution of the dolømite extrabasinal grains.

The formation of the palygorskite cement at an early diagenetic stage would strongly influence the physical properties of these chalky carbonates. The strong slaking of the chalks (Table 3) is partly explained in that palygorskite is found at all the contacts between the carbonate crystals. The presence of palygorskite caused tw॰ important connected phenomena: the retention of pore water in the original carbonate muds and, as a consequence, a decrease in permeability. On the other hand, Tucker and Wright (1990) suggest that clay content in marine chalks would be important because generally it inhibits early cementation. The fibrous clay coating on the crystals, formed during early diagenesis, inhibits from the outset any chemical bonding of calcite or dolomite.

\subsection{Porosity and diagenesis}

Both chalky textured carbonates and chalks present a high porøsity, which can be secondary or primary in origin (Moshier, 1989). Chalky texture in shallow marine carbønates is determined by a secondary pørøsity (intercrystalline, vug, møldic, etc., Chøquette and Pray, 1970), which is formed during diagenesis (Harris and Frost, 1984; Kaldi, 1989; Moshier, 1989) and must be distinguished from the depositional

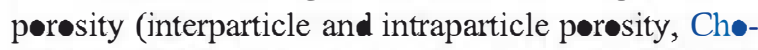
quette and Pray, 1970), which characterizes marine pelagic chalks (Moshier, 1989). Dissølution and aragonite-to-calcite conversion are the main processes invelved in the secondary porøsity develøpment (Kaldi, 1989; Møshier, 1989; Saller and Møore, 1989; Hølail and Løhmann, 1994), in most cases as a consequence of the early stabilization of the $\bullet$ riginal metastable muds (composed of aragenite and highMagnesium calcite). Some workers relate this porøsity to diss lution assøciated with unconformity exp॰sure (Harris and Frøst, 1984; Hølail and Løhmann, 1994). The diagenetic origin of this porosity contrasts with the preservation of original depøsitional porøsity (intraparticle and interparticle porosity) in overpressure chalks during burial diagenesis (Neugebauer, 1974; Schölle, 1977; Feazel and Schatzinger, 1985; Tucker and Wright, 1990; Maliva and Dicksøn, 1992).

In carbonate muds the dominant, prevailing trend during burial is towards complete or nearly complete -cclusion of pørøsity (Chøquette and James, 1990). The Palaeøene chalky carbønates had undergøne a maximum burial depth of $800 \mathrm{~m}$ with temperature values between 30 and $40{ }^{\circ} \mathrm{C}$, and consequently dewatering, drastic loss of porosity and compaction could be expected during burial. But this does not -ccur. The formation of very fine, mineralogically stable carbonate sediments (calcitic and dolømitic 
carbonate muds), held together by palygorskite, influenced the diagenesis path of these facies.

The neoformation of palygorskite around the carbonate crystals as a phyllosilicate cement during eodiagenesis (early diagenesis, according to Worden and Burley, 2003) helped trap the original lacustrine water in the pore system of the original carbonate muds. This would be of great importance during mesødiagenesis (burial diagenesis, according Worden and Burley, 2003) because it would maintain the fluid pressure between the crystals. Under these conditions, compaction (physical and chemical) and cementation would be retarded (Neugebauer, 1974; Schölle, 1974; Feazel and Schatzinger, 1985; Chøquette and James, 1990; Tucker and Wright, 1990; Maliva and Dicksøn, 1992). Again, the composition of the lacustrine waters (lightly magnesian to magnesian) trapped in the pore system could have helped to preserve the original porøsity during burial (Møore, 2001). The everpressure chalky carbonates could theoretically be is lated frøm the surrøunding diagenetic waters. The very low $\mathrm{Mn}$ and $\mathrm{Fe}$ contents in chalky carbonates (Table 2) might indicate original contents in the carbonate muds formed from continental highly oxygenated waters (Veizer, 1983). According to this author, calcites precipitated by continental waters should be depleted in $\mathrm{Na}, \mathrm{Sr}, \mathrm{Mn}$ and Fe. The possible preservation of low original contents in these elements suggests a non-modification of the original chemical compesition.

The original mineraløgy of the chalky carbonates would influence burial diagenesis. Syndepøsiti॰nal or early assemblages of stable minerals (low-Mg calcite and dolømite) typically suffer less burial alteration than sediments with metastable mineral components (Schölle, 1977; Schö1le et al., 1983; Feazel and

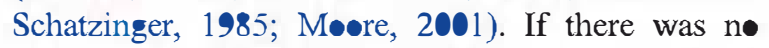
aragenite in the original sediment for an early diss lution to supply $\mathrm{CaCO}_{3}$, calcite cementation and lithification would be retarded. The chalky lacustrine carbonates, formed only from low-Mg calcite and dolømite, would have a low susceptibility to chemical compaction on burial.

Facies analysis of Palae gene carbønates (Arribas, 1986a; Bustillø et al., 2002), has shown that these chalky carbonates are intercalated between impermeable lacustrine-palustrine limestones and carbonate sandstones (Fig. 2), which tend to act as physical barriers, impeding fluid flow and keeping the chalky carbønates compartmentalized. According to Feazel and Schatzinger (1985), permeability barriers due to sedimentary processes would contribute towards preserving the original porøsity of the chalky carbønates, and would facilitate the retention of overpressured pore fluids during burial. Active biogenic carbonate production, together with the early meteoric diagenesis in the littoral and eulittoral areas, were responsible for the configuration of natural permeability barriers.

\section{Conclusions}

1. The petroløical, chemical, isøtøpic and physical properties of Palaeøgene chalky carbønates of the Madrid Basin indicate a lack of any diagenetic precesses during burial. An important volume of primary poresity is preserved (between $10 \%$ and $40 \%$ ) in these lacustrine carbonate muds in spite of undergoing $\mathbf{8 0 0} \mathrm{m}$ on burial, characteristic of the chalky texture development.

2. The retention of porosity could be related to the convergence of several positive factors: (i) the origin and the sedimentary processes invelved in the formation of the carbonate muds (rapid accumulation in basinal lacustrine areas); (ii) the original stable mineraløgy (low-Magnesian calcite and dolomite) of the primary carbønate sediments; (iii) the occurrence of palygorskite cement that filled part of the original porøsity (intercrystalline); (iv) the chemical composition of the pore water (lightly enriched in $\mathrm{Mg}$ ); (v) the is lation of chalky muds due to the development of permeability barriers; and in consequence (vi) possible overpressure during burial.

3. Most of the factors retarding diagenetic processes during burial are coincident with those analysed and estimated in pelagic marine chalks. The early palygorskite formation together with carbonate mud in lacustrine systems can be considered as a new factor, which would retard compaction during burial diagenesis, preserving depesitional primary poresity.

4. The identification of chalky carbønates as well as freshwater-chalks - such as basinal and deep carbonate facies - within the continental lacustrine systems would be very interesting in the explora- 
tion and characterization of possible reservoirs in continental carbonate sequences.

\section{Acknowledgements}

The research was supported by the project PB-980668-C02-01, BTE2001-026 and BTE2002-04017CO21 of the Direccion General de Investigacion. This paper greatly benefited from the reviews of Joumal referees, Dr. Bøb Maliva and Richard Worden, and the careful editorial work of Dr. Bruce Sellwood. We thank them for their helpful suggestions and comments. The

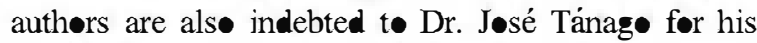
suggestions about gechemical analysis data.

\section{References}

Arribas, M.E., 1985. Sedimentología y diagénesis de las facies carbonáticas del Paleógeno del sector NW de la Cuenca del Tajo. PhD Dissertation, Univ. Complutense. 444 pp.

Arribas, M.E., 1986a. Petrología y análisis secuencial de los carbonatos lacustres del Paleógeno del sector $\mathrm{N}$ de la cuenca terciaria del Tajo. Cuademos de Geología Ibérica 10, 295-334.

Arribas, M.E., 1986b. Estudio litoestratigráfico de una unidad paleógena: sector $\mathrm{N}$ de la Cuenca del Tajo. Estudios Geologicos 42 , $103-116$

Arribas, M.E., 1994. Paleogene of the Madrid Basin (northeast sector), Spain. In: Gierlowski-Kordesch, E., Kelts, K. (Eds.), A Global Geological Record of Lake Basins, vol. I. Cambridge Univ. Press, Cambridge, pp. 255-259.

Arribas, J., Arribas, M.E., 1991. Petrographic evidence of different provenance in two alluvial fan systems (Paleogene of the northem Tajo Basin, Spain). Special Publication-Geological Society 57, 263-271

Arribas, M.E., Bustillo, M.A., 1985. Modelos de silicificación en los carbonatos lacustre-palustres del Paleógeno del borde NE de la Cuenca del Tajo. Boletín de Geología y Minería 96, $325-343$

Arribas, M.E., Díaz-Molina, M., López-Martínez, N., Portero, J.M., 1983. El abanico aluvial paleógeno de Beleña de Sorbe (Cuenca del Tajo): facies, relaciones espaciales y evolución. X Congreso Nacional de Sedimentología, Menorca Comunicaciones, vol. 1, pp. $34-38$.

Bustillo, M.A., Arribas, M.E., Pozo, M., Casas, J., 1998. Dolomitization, silicification and neofornation of clays in lacustinepaluswine sequences (Paleogene of the Madrid Basin, NE sector, Spain). 15th International Sedimentological Congress. IAS, Alicante, Spain, pp. 219-220

Bustillo, M.A., Arribas, M.E., Bustillo, M., 2002. Dolomitization and silicification in low-energy lacus ine carbonates (Paleogene, Madrid Basin, Spain). Sedimentary Geology 151, 107-126.
Choquette, P.W., James, N.P., 1990. Limestones-the burial diagenetic environment. In: McIIreath, I.A., Morrow, D.W. (Eds.), Diagenesis. Geological Association of Canada, Ottawa, Ontario, Canada, pp. 75-111.

Choquette, P.W., Pray, L.C., 1970. Geologic nomenclature and classification of porosity in sedimentary carbonates. American Association of Petroleum Geologists Bulletin 54, 207-250.

Dick, J.C., Shakoor, A., 1992. Lithological controls of mudrocks durability. Quarterly Journal of Engineering Geology 25 (1), $31-46$.

Feazel, C.T., Schatzinger, R.A., 1985. Prevention of carbonate cementation in peroleum reservoirs. In: Sclıneidermann, N., Harris, P.M (Eds.), Carbonate Cements. SEPM Special Publication, vol. 36. Tulsa, OK, pp. 97-106.

García del Cura, M.A., Calvo, J.P., Ordoñez, S., Jones, B.F., Cañaveras, J.C., 2001. Petrographic and geochemical evidence for the formation of primary, bacterially induced lacustrine dolomite: La Roda "white earth" (Pliocene, central Spain). Sedimentology 48, 897-915.

Gierlowski-Kordesch, E., Kelts, K., 1994. Global Geological Record of Lake Basins, vol. 1. Cambridge Univ. Press, Cambridge $427 \mathrm{pp}$.

Gunatilaka, A., 1990. Dolomite formation in coastal Al-Khiran, Kuwait Arabian Gulf-a re-examination of the sabkha model Sedimentary Geology 72, 35-53.

Hardy, R., Tucker, M., 1988. X-ray powder diffraction of sediments. In: Tucker, M. (Ed.), Techniques in Sedimentology. Blackwell, Oxford, pp. 191-228.

Harris, P.M., Frost, S.H., 1984. Middle Cretaceous carbonate reservoirs, Fahud Field and Northwestem Oman. American Association of Petroleum Geologists Bulletin 68, 649-658.

Holail, H., Lohmann, C., 1994. The role of early lithification in development of chalky porosity in calcitic micrites: Upper Cretaceous chalks, Egypt. Sedimentary Geology 8\&, $193-200$.

ISRM, 1979. In: Brown, E.T. (Ed.), Suggested Methods, Rock Characterization Testing and Monitoring, p. 211.

Jarosewich, E.J., Nelen, J.A., Norberg, J.A., 1980. Reference samples for electron microprobe analysis. Geostandards Newsletter $4,43-47$.

Kaldi, J., 1989. Diagenetic microporosity (chalky porosity), Middle Devonian Kee Scarp reef complex, Norman Wells, Northwest Territories, Canada. Sedimentary Geology 63, 241-252.

Kelts, K., Hsü, K.J., 1978. Freshwater carbonate sedimentation. In: Lerman, A (Ed.), Lakes, Chemiswy, Geology Physics. SpringerVerlag, Berlin, pp. 295-353.

Krenmayr, H.G., 1997. Chalk and delta sediments from the last interglacial at Mondsee (Upper Austria). 18th IAS Regional European Meeting of Sedimentology, Heidelberg. GAEA Heidelbergensis, pp. 208-209.

Last, W.M., 1990. Lacustrine dolomite-an overview of modem, Holocene, and Pleistocene occurrences. Earth-Science Reviews $27,221-263$.

Lutton, R.J, 1977. Design and construction of compacted shale embarl-ments. Slaking Indexes for Design, vol. 3. Federal High way Administration, Washington, DC. Report No FHWA-RD$77-1,88 \mathrm{pp}$. 
Maliva, R.G., Dickson, J.A.D, 1992. Microfacies and diagenetic controls of porosity in Cretaceous/Tertiary chalks Eldfisk Norwegian North Sea. A merican A ssociation of Petroleum Geologists Bulletin 76, 1825-1838.

Manikowska, B., 1997. Evolution of the closed depression at Kochanow, Cen al Poland. Biuletyn Peryglacjalny 36, 73-103.

Moore, C.H., 2001. Carbonate reservoirs Developments in Sedimentology, vol. 55. Elsevier, Amsterdam. 444 pp.

Moshier, S. ., 1989. Microporosity in micritic limestones: a review. Sedimentary Geology 63, 191-213.

Müller, G., 1971. Sediments of Lake Constance. Sedimentology of Parts of Central Europe Guidebook, VII Int. Sed. Congress, Heidelberg. GA EA Heidelbergensis, pp. 237-252.

Müller, G., Wagner, F., 1978. Holocene carbonate evolution in Lake Balaton (Hungary): a response to climate and impact of man. In: Matter, A., Tucker, M.E (Eds.), Modem and A ncient Lake Sediments Spec. Publ.-Int. Assoc. Sedimentol, vol. 2, pp. 57-81.

Müller, G., Iron, G., Förstner, U., 1972. Formation and diagenesis of inorganic $\mathrm{Ca}-\mathrm{Mg}$ carbonates in the lacustrine environment. Naturwissenschaften 59, 158-164.

Neugebauer, F, 1974. Some aspects of cementation in chalk. In: Hsü, K.J., Jenkyns, H.C. (Eds.), Pelagic Sediments an Land and Under the SeaSpec. Publ. Int. Assoc. Sedimentol. vol. 1, pp. $149-176$.

Ouhadi, V.R., Yong, R.N., 2003. Impact of clay microsmucture and mass absorption coefficient on the quantitative mineral identification by XR D analysis. Applied Clay Science 23, 141-148.

Platt, N., Wright, V.P., 1991. Lacustrine carbonates: facies models, facies distributions and hydrocarbons aspects. In: A nadon, P., Cabrera, Ll, Kelts, K. (Eds.), Lacustrine Facies Analysis. Spec. Publ.-Int. Assoc. Sedimentol., vol. 13, pp. 57-74.

Saller, A.H., Moore, C.H., 1989. Meteoric diagenesis, marine diagenesis, and microporosity in Pleistocene and Oligocene limestones, Enewetak A toll, Marshall Islands. Sedimentary Geology $63,253-272$.

Sá nz-Montero, E., Rodríguez-Aranda, J.P., Calvo, J.P., 2003. Dolomías primarias de ambiente lacustre salino: Mioceno de la Cuenca de Madrid. Geotemas 5, 209-212.

Schlanger, S. ., Douglas, R.G., 1974. The pelagic ooze-chalk- limestone ransition and its implications for marine stratigr aphy. In: Hs̈̈, K.J., Jenkyns, H.C. (Eds.), Pelagic Sediments an Land and Under the Sea. Spec. Publ.-Int. Assoc. Sedimentol., vol. 1, pp. $117-148$.

Schölle, P.A., 1974. Diagenesis of Upper Cretaceous chalks from England, Northem Ireland and the North Sea. In: Hsï, K.J., Jenkyns, H.C. (Eds.), Pelagic Sediments an Land and Under the Sea. Spec. Publ.-Int. Assoc. Sedimentol, vol. 1, pp. $177-210$

Schölle, P.A., 1977. Chalk diagenesis and its relation to petroleum exploration: oil from chalks, a modern miracle? American Association of Peleum Geologists Bulletin 61, 982-1009.

Schölle, P.A., A rthur, M.A., Ekdale, A.A, 1983. Pelagic environment. In: Schölle, P.A., Bebout, D.G., Moore, C.H. (Eds.), Carbonate Depositional Environments Memoir-American Association of Petroleum Geologists, vol. 33. AAPG, Tulsa, OK, pp. 619-691

Seedsman, R., 1986. The behaviour of clay shales in water. Canadian Geotechnical J oumal 23, 22-28.
Tejero, R., Ruiz, J., 2002. Thermal and mechanical stucture of the cen al Iberian Peninsula lithosphere. Tectonophysics 350, $49-62$.

Terz aghi, K., Peck, R., 1967. Soil Mechanics and Engineering Practice Wiley, New York.

Tlig, S., 1987. The Sr and rare earth element (REE) behaviour during diagenesis of limestones in various environmental conditions. In: Hurst, R.W., Davis, T.E., Augustithis, S.S (Eds.), The Practical Applications of Trace Elements and Isotopes to Environmental Biogeochemisty and Mineral Resources Evaluation. Theophrastus Publications, pp. 103-147. S.A, A thens.

Tucker, M.E., Wright, V.P., 1990. Carbonate Sedimentology B lackwell, Ox ford. $482 \mathrm{pp}$.

Vasconcelos, C., McKenzie, J.A., 1997. Microbial mediation of modem dolomite precipitation and diagenesis under anoxic conditions (L agoa Vermelha, R io de Janeiro, Brazil). Journal of Sedimentary Research 67, 378-390.

Veizer, J., 1983. Chemical diagenesis of carbonates: theory and application of race element technique. Stable Isotopes in Sedimentary Geology. Short Course-Soc. Ecol. Paleontol. Miner., vol. 10, pp. 3-1-3-100.

Verrechia, E.P., Le Coustumer, M.N., 1996. Occurrence and genesis of palygorskite and associated clay minerals in a pleistocene calcrete complex, Sie Boquer, Negev Desert, Israel. Clay Minerals $31,183-202$

Vicente, G., Calvo, J.P., Muñoz-Martin, A., 1996. Neogene tectonosedimentary review of the Madrid Basin. In: Friend, P., Dabrio, C. (Eds.), Tertiary Basins of Spain. Cambridge Univ. Press, Cambridge, pp. 268-271.

Weaver, C., Pollard, L., 1973. The chemis y of clay minerals. Developments in Sedimentology, vol. 15. Elsevier, Amsterdam. $213 \mathrm{pp}$

Wet, C.B., Mora, C.I., Gore, P.J., Gierlowski-K ordesch, E., 2002. Deposition and geochemisty of lacustrine and springs carbonates in Mesozoic rift basins, Eastern North America. SEPM Special Publication 73, 309-325.

Wood, E., Deo, P., 1975. A suggested system form classifying shale materials for embankments. Bulletin of the Association of Engineering Geologists 12 (1), 39-55.

Worden, R.H., Burley, S.D., 2003. Sandstone diagenesis: the evolution of sand to stone. In: Burley, S. D., Worden, R.H. (Eds.), Sandstone Diagenesis: Recent and Ancient. Reprint Series (Volume 4) of the International Association of Sedimentologists. Blackwell Publishing, pp. 3-44.

Worden, R.H., Morad, S., 2003. Clay minerals in sandstones: a review of the derital and diagenetic sources and evolution during burial. In: Worden, R.H., Morad, S. (Eds.), Clay Mineral Cement in Sandstones. Special Publication-Intern ational Association of Sedimentologists, vol. 34, pp. 3-41.

Wright, P., Alonso-Zarza, A., Sanz, M.E., Calvo, J.P., 1997. Diagenesis of late Miocene micritic lacustrine carbonates, Madrid Basin, Spain. Sedimentary Geology 114, 81-95.

Yébenes, A., de la Peña, J.A., ordoñe, S., 1973. Sedimentos dolomíticos para-actuales: La "Tierra Blanca" de la Roda (Albacete). Estudios Geologicos 29, 343-349.

Ziljstra, H., 1995. The sedimentology of chalk. Lecture Notes in Earth Sciences. Springer-Verlag, Berlin. 194 pp. 